\title{
Effect of organic and inorganic fertilizers on penology of Maize varieties
}

\author{
Shah Faisal ${ }^{1,2 *}$, Bashir Ahmad ${ }^{1}$, Inamullah ${ }^{1}$, Kashif Akhtar ${ }^{1,2}$, Shahzad \\ $\mathrm{Ali}^{1,2}$ and Ihteram Ullah ${ }^{3}$ \\ 1Department of Agronomy, The University of Agriculture Peshawar, Pakistan \\ 2College of Agronomy, Northwest A \& F University, Yangling, Shaanxi, China \\ 3Department of Plant Breeding and Genetics, Gomal University, D.I. Khan, Pakistan \\ *Corresponding Author e-mail: shahfaisaldargai@gmail.com \\ Citation \\ Shah Faisal, Bashir Ahmad, Inamullah, Kashif Akhtar, Shahzad Ali and Ihteram Ullah. Effect of organic and \\ inorganic fertilizers on penology of maize varieties. Pure and Applied Biology. Vol. 4, Issue 3, 2015, pp 434-440. \\ http://dx.doi.org/10.19045/bspab.2015.43020
}

Received: 03/04/2015 Revised: 18/08/2015

Accepted: 24/08/2015

\section{Abstract}

The performance of organic and inorganic fertilizers have shown positive effects on plant growth in crop production, a study was conducted to measure the effect of various levels of organic and inorganic fertilizers in maize. The experiment was conducted in randomized complete block design with split plot arrangement having three replications at New Development Farm, Khyber Pakhtunkhwa Agricultural University Peshawar during kharif 2009-10. Various organic fertilizers namely, (1) Higo plus (500 $\left.\mathrm{kg} \mathrm{ha}^{-1}\right)$, farm yard manure (10 tons per hectare) both were incorporated in the soil before sowing (2) Mexicrop (500 liters in 100 liters of water) was sprayed after emergence. NP fertilizers was applied as an inorganic fertilizers source under following rates; 120:80, 150:100 and 180:120 kg ha-1 at sowing, whole $\mathrm{P}$ was applied at once, but nitrogen was applied in split doses. Organic and inorganic fertilizers and control were kept in main plot. While maize varieties (i.e. Jalal, Pahari and Azam) were sown in sub plots. Delayed tasseling (62.2), silking (71.1) maturity (98.6), taller plants $(175 \mathrm{~cm})$, plants population at harvest $\left(61481 \mathrm{ha}^{-1}\right)$ and biological yield $\left(11111 \mathrm{~kg} \mathrm{ha}^{-1}\right)$ were recorded when NP was applied at the rate of $180: 120 \mathrm{~kg} \mathrm{ha}^{-}$ ${ }^{1}$, whereas highest harvest index (37.1\%) and maximum plants population at harvest (65556) were recorded when NP at 150:100 $\mathrm{kg} \mathrm{ha}^{-1}$ was used. Jalal variety emerged as best variety with delayed tasseling (61.20), silking (68.6) and produce taller plants $(171 \mathrm{~cm})$ with maximum biological yield $\left(10234 \mathrm{~kg} \mathrm{ha}^{-1}\right)$. In conclusion inorganic source of fertilizers (NP) proved better than organic and Jalal variety is strongly recommended because of better performance in the agro-climatic condition of Peshawar.

Keywords: Organic \& inorganic fertilizer; Phenology; Maize varieties.

\section{Introduction}

Maize (Zea mays L.) is the most efficient, productive and industrial cereal crop of the world. After wheat and rice, it ranks third in Pakistan in terms of production and grown as a dual purpose such as food, feed, and fodder crop. Maize is chemically composed of $72 \%$ starch, $10 \%$ protein, $8.5 \%$ fiber and $1.7 \%$ ash. It plays significant role in both human diet animal feed and provides a large amount of energy and protein $[1,2]$. Maize also provide a great amount of raw materials for production of various stuffs such as corn starch, oil, cosmetics, wax and alcohol. 
Maize takes 3 to 4 months for complete maturity and generally open pollinated varieties are sown. The large producers of maize are India, Pakistan, Brazil, France, and Italy. Though the soil and climatic conditions of Pakistan is good for the maize production, but it ha ${ }^{-1}$ fodder yield is very low as compared to other countries of the world. Low yield of maize was due to a lot of factors, but fertilizer application is one of the key factors which can increase fodder production on per unit area basis [1, 2].

In Pakistan, the area under maize cultivation and its total production during 2009 was 1052.1000 ha and 3593 thousand tons respectively, with an average yield of 3415 $\mathrm{kg} \mathrm{ha}{ }^{-1}$. In Khyber Pakhtunkhwa the total production was 959.9 thousand tons with an average yield of $1880 \mathrm{~kg} \mathrm{ha}^{-1}$ [3].

Production of crop and soil fertility dramatically enhanced by nitrogen application [4] increased bio mass (25-42\%) in maize was conveyed as a result of nitrogen application [5]. The nitrogen applications has positively improved the penology of crop, also increase the rate of germinations and increased the number of plants [6]. Increase in yield and penology of maize crop varieties use high quantity of $\mathrm{N}$ fertilizer in split doses [7]. Generally, nitrogen application adds 18$34 \%$ of residual nitrogen [8] and increased mineralization (4-9.4\%) was also observed in soil total nitrogen [9]. Maize production is limited as result of low amount of phosphorus in soil coupled with its fixation by oxides of iron and aluminum [10]. Phosphorus application increased fodder yield and quality by increasing plant height, and the number of leaves plant. Phosphorus differs from nitrogen in the way that it doesn't undergo biological nitrogen fixation. Consequently, application of phosphorus from both organic and inorganic resources is compulsory for maximizing and sustaining high yield potential and for consistence of cultivation systems.
Keeping in view the above, a field experiment was arranged to study the effects of organic and inorganic fertilizers on phenology of maize varieties.

\section{Materials and Methods}

A field experiment entitled "Effect of organic and inorganic fertilizers on Phenology of maize varieties" was conducted at New Developmental Farm, KP Agricultural University, and Peshawar, Pakistan during kharif season 2010. The experiment was laid out in Randomized complete block design with split plot arrangement, replicated three times. Main plots consisted fertilizer i.e. F1 (Control), F2 (HIGO Organic Plus $=500 \mathrm{~kg}$ ha-1), F3 (Mexicrop Sea-Gold = 500L/100L water ha-1 ), F4 (FYM = $10 \mathrm{t}$ ha-1), F5 (Nitrogen and Phosphorous with ratio 120:80 kg ha-1), F6 (Nitrogen and Phosphorous with ratio 150:100 $\mathrm{kg} \mathrm{ha}^{-1}$ ) and $\mathrm{F} 7$ (Nitrogen and Phosphorous with ratio180:120 $\mathrm{kg} \mathrm{ha}^{-1}$ ), while sub plots consisted varieties i.e. Jalal, Pahari and Azam. The size of sub plot was $5 \mathrm{~m} \times 4.5 \mathrm{~m}$.

The field was ploughed thoroughly and a fine seedbed was prepared with the help of rotavator. Seeds were sown with $75 \mathrm{~cm}$ row to row distance and $20 \mathrm{~cm}$ plant to plant distance was maintained after germination with hand thinned in July, 2010. Phosphorous was applied in the form of diammonium phosphate $(46 \% \mathrm{P})$ before seed sowing at the time of seedbed preparation as per treatment required. Nitrogen was applied in split dose i.e. half at sowing and remaining half was applied at first irrigation in the form of urea $(46 \% \mathrm{~N})$ as per treatment required. HIGO organic plus and farm yard manure (FYM) was incorporated in soil, while Mexicrop Sea-Gold was sprayed after the emergence of the crop. Weeds were controlled manually by hoeing. The crop was irrigated when needed. All other cultural practices were carried out uniformly in all plots. The data were recorded included Days to emergence, emergence $\mathrm{m} 2$, Days to $50 \%$ tasseling, Days to $50 \%$ silking, 
Plant height $(\mathrm{cm})$, Days to physiological maturity, Plants at harvest (ha-1), Biological yield $\left(\mathrm{kg} \mathrm{ha}^{-1}\right)$ and Harvest index $(\%)$.

Data on days to emergence were recorded by counting number of days from sowing to the date on which $50 \%$ seedlings emerged and data regarding emergence $\mathrm{m}^{2}$ were recorded by counting the number of plants in one meter row at five various places in each subplot, converting into $\mathrm{m}^{2}$ area and then averaged. Days to tasseling were recorded by counting number of days from sowing to the date on which $50 \%$ plants produced tassels. Days to silking were counted from the date of sowing to the date on which $50 \%$ plants produced silk. Data regarding plant height was recorded by selecting five plants randomly and measured their heights from the base to the tip of tassel by measuring tape in each treatment plot. Days to maturity were counted from the date of sowing till black layer appeared and the tissues started degeneration. Plants were counted in central four rows in each sub plot at harvest and then converted into plants ha-1. Biological yield was recorded by weighing all the plants harvested from central four rows in each subplot and then converted into $\mathrm{kg}$ ha- 1 . Harvest index was calculated using the following formula:

[Harvest Index $(\%)=($ Grain yield/Biological yield) $x$ 100]

The replicated means were subjected to ANOVA using MS excel (2007). The least significant difference (LSD) was founded by using $\mathrm{p}<0.05$ that shows the results were significantly different.

\section{Results}

\section{Days to emergence}

Mediation of data exhibited that various organic and inorganic treatments and varieties had not significantly influenced days to emergence of maize presented in table 1. The interaction between treatments and varieties was not significant. Days to emergence ranged from 7 to 10 for both varieties and organic and in organic treatments.

\section{Emergence m ${ }^{2}$}

Statistical analysis of the data exposed that various organic and inorganic treatments and varieties had not significantly influenced emergence $\mathrm{m}^{2}$ in maize showed in table 2 . Interaction between treatments and varieties was not significant.

\section{Days to tasseling}

Perusal of data showed that organic and inorganic treatments and varieties had significantly influenced days to tasseling showed in table 1 . The interactive effect of various organic and inorganic treatments and varieties was found not significant (Table 1). Tasseling was delayed (62 days) in plots having received NP (180:120) treatment while early tasseling (52 days) was recorded in control plots. In case of varieties, delayed (61days) tasseling was observed in Jalal variety while Pahari variety showed early (56 days) tasseling.

\section{Days to silking}

Statistical data showed that organic and inorganic treatments and varieties had significantly influenced days to silking. The interactive effect of various organic and inorganic treatments and varieties was found not significant (Table 1). Silking was delayed (71 days) in plots having received NP (180:120) treatment while early silking (59 days) was recorded in control plots. In term of varieties, delayed (68) days silking was absorbed in plots sown with Jalal and early (64 days) silking was noticed in Pahari.

\section{Days to 50\% silking}

Data regarding days to silking showed in table 2 that organic and inorganic treatments and varieties had significantly influenced days silking. The interactive effect of various organic and inorganic treatments and varieties was found not significant. Silking was delayed (71 days) in plots having received NP (180:120) treatment while early silking (59 days) was recorded in control 
plots. In term of varieties, delayed (68) days silking was absorbed in plots sown with Jalal and early (64 days) silking was noticed in Pahari.

\section{Plant height (cm)}

Data regarding plant height presented in table 2. Statistical data revealed that organic and inorganic treatments and varieties had significantly influenced plant height. The interaction between treatments and varieties was not significant. Maximum height of plant $(175 \mathrm{~cm})$ was recorded in plots fertilized with treatment NP (180:12). Minimum height $(141 \mathrm{~cm})$ was attended in control plot. While in varieties, Jalal was taller $(171 \mathrm{~cm})$ and Pahari was shorter $(154 \mathrm{~cm})$ one.

\section{Days to physiological maturity}

Days to physiological maturity was showed in table 2. Mediation of data showed that various organic and inorganic treatments and varieties had significantly inclined on days to physiological maturity. The interaction between treatments and varieties was not significant. However, more days to maturity (98) were absorbed in treatment NP (180:120) and lower days to maturity (91) were recorded in control.

\section{Plants at harvest $\left(\mathrm{ha}^{-1}\right)$}

Data concerning plants at harvest were presented at table 2. Plant at harvest Statistical analysis of data reflected that plant at harvest was significantly affected by various organic and inorganic treatments. While varieties and interaction was found not significant. Maximum (61481) plant at harvest was found in plot fertilized with treatment NP (180:120) and minimum (54815) were received in control.

\section{Discussion}

Various organic and inorganic fertilizer sources significantly affected days to tasseling and silking of maize. Tasseling and silking was delayed from those plots where inorganic fertilizer $\mathrm{N}$ : $\mathrm{P}$ was used at the rate of 180:120 compared to control plots where tasseling and silking was enhanced. This is due to the fact that delayed tasseling and silking was because of increasing inorganic fertilizers. Similar results were found by [11] who reported that increased application of NP levels delayed tasseling. In case of silking, similar trend was observed as that of tasseling. The results are in line with those of $[12,13]$ who observed delayed silking with increasing level of inorganic fertilizers. Similarly, tasseling and silking was delayed by Jalal followed by Azam and enhanced by Pahari. It might be due to the genetic makeup of the varieties. The results are in line with those of $[12,11]$ who stated that varieties had a significant effect on days to tasseling. While in silking the result are in contrast.

Plant height and leaves plant ${ }^{-1}$ were significantly affected by various organic and inorganic fertilizer. Taller plants and more leaves plant- 1 were observed in plots treated with inorganic fertilizer of $\mathrm{N}: \mathrm{P}$ at the rate of 180:120. Nitrogen and other fertilizer played a vital role in growth of plants and improving its production [14]. Organic sources of nitrogen resulted in stunted plants [15]. This can be attributed to the fact that more leaves plant-1 was produced by increasing inorganic fertilizer which alternatively improved vegetative growth of maize [16] Stunted plants and lesser leaves were observed in control plots. Jalal produced taller plants and increased leaves plant-1 as compared to others. This might due to the genetic makeup of maize cultivars. Similar sort of results were observed by $[17,18]$ who stated that plant height was significantly affected by cultivars.

Days to physiological maturity was significantly affected by organic and inorganic fertilizers and had non-significant on varieties. Maturity was delayed by using high dose of N:P 180:120 and was enhanced by control plots. It might be due to the fact that inorganic nitrogen was readily available which ultimately enhanced the vegetative growth which indirectly resulted in delayed 
maturity. [13] reported delayed maturity with increasing NP levels. In case of varieties, results are in contrast with those of [17] who stated that days to maturity differed significantly in case of varieties due to the genetic makeup.

Data regarding plant harvest was significantly affected by various organic and inorganic treatments. More plants at harvest were recorded by the application of NP (180:120) as compared to less in control. The higher number of plants with highest dose of inorganic nitrogen might be attributed to the fact that inorganic nitrogen produced more plants because of being readily available for plants [6].

Table 1. Days to emergence, emergence $\mathrm{m}^{-2}$, Days to $50 \%$ tasseling, of maize varieties as affected by organic and inorganic fertilizers.

\begin{tabular}{llll}
\hline Varieties & Days to emergence & Emergence $\mathrm{m}^{-2}$ & Days to tasseling \\
\hline Jalal & 7.86 & 13 & $61 \mathrm{a}$ \\
Pahari & 7.67 & 13 & $56 \mathrm{~b}$ \\
Azam & 8.14 & 12.2 & $58 \mathrm{~b}$ \\
LSD $(0.05)$ & $\mathrm{Ns}$ & $\mathrm{Ns}$ & 2.10 \\
\hline Control & 7.89 & 12.5 & $54 \mathrm{~d}$ \\
HIGO O.P.(500 kg) ha $\left.{ }^{-1}\right)$ & 7 & 13.6 & $55 \mathrm{~cd}$ \\
Mexicrop $\left(500 \mathrm{liters}^{-1} \mathrm{ha}^{-1}\right)$ & 8.11 & 12.9 & $57 \mathrm{bc}$ \\
FYM $(10$ tons ha-1) & 7.67 & 11.8 & $60 \mathrm{a}$ \\
NP(120-80 kg ha-1) & 7.33 & 13.3 & $60 \mathrm{ab}$ \\
NP(150-100 kg ha-1) & 7.89 & 12.1 & $60 \mathrm{a}$ \\
NP(180-120 kg ha-1) & 9.33 & 13 & $62 \mathrm{a}$ \\
LSD $(0.05)$ & $\mathrm{Ns}$ & $\mathrm{Ns}$ & 2.69 \\
\hline V $\times$ OI (Interaction) & $\mathrm{Ns}$ & $\mathrm{Ns}$ & $\mathrm{Ns}$ \\
\hline
\end{tabular}

$\mathrm{V}=$ Varieties

$\mathrm{OI}=$ Organic and Inorganic fertilizers 
Table 2. Days to $50 \%$ silking, Plant height $(\mathrm{cm})$, Days to physiological maturity, of maize varieties as affected by organic and inorganic fertilizers.

\begin{tabular}{|c|c|c|c|c|}
\hline Varieties & Days to silking & $\begin{array}{l}\text { Plant height } \\
(\mathrm{cm})\end{array}$ & Days to maturity & $\begin{array}{l}\text { Plant at harvest } \\
\left(\mathrm{ha}^{-1}\right)\end{array}$ \\
\hline Jalal & $68 \mathrm{a}$ & $171 \mathrm{a}$ & 95.7 & 58413 \\
\hline Pahari & $64 \mathrm{~b}$ & $154 \mathrm{c}$ & 95.5 & 57937 \\
\hline Azam & $65 \mathrm{~b}$ & $166 \mathrm{~b}$ & 95.9 & 62381 \\
\hline LSD (0.05) & 2.16 & 4.05 & Ns & Ns \\
\hline Control & $59 \mathrm{~d}$ & $141 \mathrm{e}$ & 91.9 ef & $54815 \mathrm{~b}$ \\
\hline HIGO O.P.(500 kg) ha' & $60 d$ & $165 \mathrm{c}$ & $95.1 \mathrm{cde}$ & $55556 \mathrm{~b}$ \\
\hline Mexicrop (500 liters) $\mathrm{ha}^{-}$ & $64 \mathrm{c}$ & $158 \mathrm{~d}$ & 95.2 cde & $61111 \mathrm{ab}$ \\
\hline FYM (10 tons ha $\left.{ }^{-1}\right)$ & $68 b$ & $171 \mathrm{ab}$ & 96.7 bcd & $54074 \mathrm{~b}$ \\
\hline $\mathrm{NP}\left(120-80 \mathrm{~kg} \mathrm{ha}^{-1}\right)$ & $68 b$ & $167 \mathrm{bc}$ & $96.1 \mathrm{bcd}$ & $65556 \mathrm{a}$ \\
\hline NP(150-100 kg ha-1) & $70 \mathrm{ab}$ & $170 \mathrm{abc}$ & $97.3 \mathrm{abcd}$ & $64444 \mathrm{a}$ \\
\hline NP(180-120 kg ha-1) & $71 \mathrm{a}$ & $175 \mathrm{a}$ & $98.6 \mathrm{abc}$ & $61481 \mathrm{ab}$ \\
\hline $\operatorname{LSD}(0.05)$ & 2.83 & 5.36 & 2.6446 & 8328.7 \\
\hline $\mathrm{V} \times \mathrm{OI}$ (Interaction) & Ns & Ns & Ns & \\
\hline
\end{tabular}

Table 3. Plants at harvest $\left(\mathrm{ha}^{-1}\right)$, Biological yield $\left(\mathrm{kg} \mathrm{ha}^{-1}\right)$, Harvest index, of maize varieties as affected by organic and inorganic fertilizers.

\begin{tabular}{|c|c|}
\hline Varieties & Plant at harvest $(()$ \\
\hline Jalal & 58413 \\
\hline Pahari & 57937 \\
\hline Azam & 62381 \\
\hline $\operatorname{LSD}(0.05)$ & Ns \\
\hline Control & $54815 \mathrm{~b}$ \\
\hline HIGO O.P.(500 kg) ha-1) & $55556 \mathrm{~b}$ \\
\hline Mexicrop (500 liters) ha-1) & $61111 \mathrm{ab}$ \\
\hline FYM $\left(10\right.$ tons ha $\left.^{-1}\right)$ & $54074 \mathrm{~b}$ \\
\hline $\mathrm{NP}\left(120-80 \mathrm{~kg} \mathrm{ha}^{-1}\right)$ & $65556 a$ \\
\hline $\mathrm{NP}\left(150-100 \mathrm{~kg} \mathrm{ha}^{-1}\right)$ & $64444 \mathrm{a}$ \\
\hline $\mathrm{NP}\left(180-120 \mathrm{~kg} \mathrm{ha}^{-1}\right)$ & $61481 \mathrm{ab}$ \\
\hline LSD (0.05) & 8328.7 \\
\hline $\mathrm{V} \times \mathrm{OI}$ (Interaction) & $\mathrm{Ns}$ \\
\hline
\end{tabular}

$\mathrm{V}=$ Varieties

\section{References}

$\mathrm{OI}=$ Organic and Inorganic fertilizers

1. Anonymous (2000) Fertilizers and Their Use. FAO, International Industry Association, Rome, 35-38.

2. Habtegebrial, K., B.R. Singh, and M. Haile. 2007. Impact of tillage and nitrogen fertilization on yield, nitrogen use efficiency of tef Eragrostis, Trotter and soil properties. Soil Till. Res. 94: 55-63.

3. Maiti, R.K. and Wesche-Ebeling, P. (1998) Maize Science. Oxford and IBH Publishing CO. Pvt. Ltd., New Dehli, Culcutta, 323 
4. MINFAL. 2009. Ministry for Food, Agriculture and Livestock. Agriculture Statistics of Pakistan. 2008-2009. Government of Pakistan, Islamabad. pp. 3-4.

5. Ogola, J.B.O., T.R. Wheeler, and P.M. Harris. 2002. Effects of nitrogen and irrigation on water use of maize crops. Field Crop Res. 78: 105-117.

6. Khan, A., A. Jan, S. Bashir, and M. Noor. 2005. Effect of nitrogen and seed size on maize crop. I: Stand and plant height. J. Agric. Soc. Sci. 1(4): 380381.

7. Moser, S.B., B. Feil, S. Jampatong, and P. Stamp. 2006. Effects of pre-anthesis drought, nitrogen fertilizer rate, and variety on grain yield, yield components, and harvest index of tropical maize. Agric. Water Manag. 81(1-2): 41-58.

8. Yang, J.Y., E.C. Huffman, R.D. Jong, V. Kirkwood, K.B. MacDonald, and C.F. Drury. 2007.

9. Li H., Y. Han, and Z. Cai. 2003. Nitrogen mineralization in paddy soils of the Taihu Region of China under anaerobic conditions, dynamics and model fitting. Geoderma. 115: 161175.

10. Warren, G. 1992. Fertilizer phosphorus sorption and residual value in tropical African soils. NRI Bulletin No. 37. Natural Resources Institute, Chatham, UK.

11. Masood, M., I.H. Shamsi, N. Hussain, and W.A. Shah. 2003. Performance of various maize varieties as affected by different NP levels. Asian J. Plant Sci. 2(7): 535-538.
12. Kruczek, A. 1998. Effectiveness of nitrogen fertilizer application on maize grown for grain in the Wielkopolska region. Roczniki nauk Rolniczych Seria. A. Produkcja Roslinna. 112: 3-4.

13. Saleem, A., A.M. Haqqani, H.I. Javed, Z. Ali, and J. Fateh. 2006. Economical level of NP-fertilizer for growing maize crop in Pakistan. Int. J. Agric. Bio. 8(4): 567-568.

14. Yadaw, R.L., R. Kumra, and R.S. Verma. 1990. Effects of nitrogen applied through new carriers on yield and quality of sugar can. J. Agric. Sci. Cambridge. 114: 225-230.

15. Shah, S.T.H., M.S.I. Zamir, M. Waseem, A. Ali, M. Tahir, W.B. Khalid. 2009. Growth and yield response of maize (Zea mays L.) to organic and inorganic sources of nitrogen. Pak. J. Life Soc. Sci. 7(2): 108-111.

16. Paradkar,, V.K. and R.K. Sharma. 1993. Effect of nitrogen fertilization on maize (Zea mays L.) varieties under rainfed condition. Indian J Agron. 38(2): 303-304.

17. Ahmad, N., A. Waheed, and F.S. Hamod. 2000. Performance of maize cultivars under late sowing conditions. Pak. J. Biol. Sci. 3(12): 2098-2100.

18. Utobo, E.B., E.O. Okporie, H.O. Oselebe, L.G. Ekwu, E.O. Ogah, and G.N. Nwokwu. 2010. Evaluation of eleven varieties of maize (Zea mays L.) in Abakaliki agricultural area, SouthernEastern Nigeria. Cont. J. Agric. Sci. 4: 42-47. 